\title{
EFEK ANALGETIK KOMBINASI EKSTRAK BUAH BELIMBING WULUH (Averrhoa bilimbi L) DAN EKSTRAK DAUN PEPAYA (Carica Papaya L.) PADA MENCIT (Mus musculus)
}

\author{
Amran Nur \\ Bagian Farmasi Sekolah Tinggi Ilmu Kesehatan Pelamonia Makassar \\ Email : amrannur70@gmail.com
}

\begin{abstract}
Starfruit fruit (Averrhoa bilimbi L.) and papaya (Carica papaya L.) containing the same are flavonoids which have activity as an analgesic. Flavonoids in both plants are thought to function as analgesics because they can inhibit prostrglandin synthesis which results in no release of pain meditors. The purpose of this study was to determine the analgesic effect on extract of starfruit fruit, papaya leaf extract, and a combination of both. starfruit fruit and papaya leaves macerated using $70 \%$ ethanol. Examining the analgesic activity of both extracts and combinations using a dose of $500 \mathrm{mg} / \mathrm{kg} \mathrm{BB}$. If the weight of the mice is $20 \mathrm{~g} / \mathrm{BB}$ then the dose variation is $1 \mathrm{mg} / 20 \mathrm{~g} \mathrm{BB}$. For the combination of the two extracts, it was made a comparison of extracts of starfruit fruit : papaya leaf extract 1: 3, 2: 2, and 1: 3 . The first group was given CMC N a $0.5 \%$ as a negative control, the second group was given mefenamic acid as a positive control, the group was then given extract test solution as an extract control. After 30 minutes, $1 \%$ acetic acid-inducing induction was given then observed mice stretching. The results showed that the fruit extract inasi komb starfruit: papaya leaf extract 1: 3 has the most excellent analgesic activity diba nding extract activity alone or in combination other.
\end{abstract}

Key words: Wuluh starfruit extract (Averrhoa blimbi L), papaya leaf extract (Carica papaya L.), analgesic effect.

\section{PENDAHULUAN}

Bangsa Indonesia telah lama mengenal dan menggunakan tanaman yang dapat berkhasiat sebagai obat untuk menanggulangi masalah kesehatan, dan lebih dikenal dengan pengobatan tradisional. Pengetahuan tentang tanaman obat telah diterapkan berdasarkan pengalaman dan keterampilan yang secara turun temurun diwariskan dari satu generasi ke generasi berikutnya. Meskipun sistem pengobatan di Indonesia sudah berkembang, pemanfaatan tanaman obat untuk pengobatan dan perawatan masih cukup tinggi. Berdasarkan Survey Sosial Ekonomi Nasional tahun 2001 , tercatat $57,7 \%$ penduduk Indonesia melakukan pengobatan sendiri tanpa bantuan medis, 31,7\% diantaranya menggunakan tumbuhan obat tradisional, dan $9,8 \%$ memilih 
Efek analgetik kombinasi ekstrak buah belimbing wuluh (Averrhoa bilimbi L) dan ekstrak daun pepaya (

cara pengobatan tradisional lainnya. ${ }^{1,5}$

Pengobatan herbal masih digunakan sebagai pengobatan utama di negara berkembang, yaitu sekitar $75-80 \%$ dari total jumLah penduduk, hal ini karena obat herbal lebih diterima dalam hal kebudayaan, lebih terjangkau, lebih sesuai didalam tubuh dan memiliki efek samping yang ringan. Beberapa tahun terakhir, pengobatan herbal di negara maju mulai meningkat. Salah satunya adalah sebagai obat penghilang rasa sakit. ${ }^{3,4}$

Analgetika atau obat penghilang nyeri adalah zat-zat yang mengurangi atau menghalau rasa nyeri tanpa menghilangkan kesadaran (perbedaan dengan anestetika umum). Asetosal merupakan salah satu analgetika perifer yang mampu meringankan atau menghilangkan rasa nyeri dengan cara merintangi terbentuknya rangsangan pada reseptor nyeri perifer. ${ }^{7,8}$

Buah belimbing wuluh (Averrhoa bilimbi L) selama ini dimanfaatkan sebagai bumbu masakan atau sayur, membersihkan noda pakaian, mengkilatkan barangbarang dari kuningan, dan sebagai bahan obat tradisional karena berkhasiat sebagai analgesik dan diuretik. ${ }^{1}$

Tanaman pepaya (Carica papaya L.) merupakan salah satu tanaman berkhasiat yang mudah ditemui di Indonesia. Banyak tanaman obat yang sudah dilaporkan mempunyai efek terapi untuk beberapa penyakit, namun pengetahuan tentang khasiat dan keamanan obat alami ini kebanyakan hanya bersifat empiris dan belum diuji secara ilmiah, salah satunya adalah tanaman pepaya (Carica papaya L.). ${ }^{3}$

Pada penelitian terdahulu menyebutkan bahwa infusa daun pepaya segar dapat memberikan efek analgetik pada mencit betina, Penelitian Sebelumnya melaporkan bahwa buah belimbing wuluh (Averrhoa bilimbi L) mengandung golongan senyawa oksalat, minyak menguap, fenol, flavonoid dan pektin. Susunan kimia terkandung dalam belimbing wuluh yaitu asam amino, asam sitrat, fenolat, ion kalium, gula serta vitamin dan mineral, juga terdiri dari serat, abu dan air. ${ }^{3}$ Sedangkan Daun pepaya (Carica papaya L.) diketahui mengandung flavonoid. Flavonoid berperan sebagai analgetik yang mekanisme kerjanya menghambat kerja enzim siklooksigenase. ${ }^{6}$ Dengan demikian akan mengurangi produksi prostaglandin oleh asam arakidonat sehingga mengurangi rasa nyeri. ${ }^{2}$ 
Efek analgetik kombinasi ekstrak buah belimbing wuluh (Averrhoa bilimbi L) dan ekstrak daun pepaya (

Alasan di kombinasikan ekstrak buah belimbing wuluh (Averrhoa bilimbi $L$ ) dengan ekstrak daun pepaya (Carica papaya L.) karena daun pepaya memiliki rasa yang pahit sedangkan buah belimbing wuluh rasanya asam, maka dari itu buah belimbing wuluh bisa menutupi rasa pahit dari daun pepaya. Dari hal tersebut, maka akan dilakukan penelitian pengujian efek analgetik dari kombinasi tumbuhan buah belimbing wuluh (Averrhoa bilimbi $L$ ) dan daun pepaya (Carica papaya L.) sebagai alternatif tumbuhan yang berkhasiat sebagai obat.

\section{METODE PENELITIAN}

Peralatan yang digunakan dalam penelitian ini adalah timbangan analitik (ACIS), blender, seperangkat alat maserasi / maserator, batang pengaduk, beacker glass, pipet tetes, cawan porselin, sendok tanduk, spuit 1 $\mathrm{mL}$ dan stopwatch. Bahan yang digunakan dalam penelitian ini adalah ekstrak buah belimbing wuluh, ekstrak daun pepaya, etanol $70 \%$, larutan stok (Na-CMC 0,5\%, Asam Asetat 1\%, Asam Mefenamat), 21 ekor mencit putih jantan.

\section{Prosedur Kerja}

\section{Persiapan Sampel}

Bahan uji buah belimbing wuluh ( Averrhoa bilimbi L ) dan daun pepaya
(Carica papaya L.) diambil di Desa Bontobiraeng Selatan, Kecamatan Bontonompo, Kabupaten Gowa, Sulawesi Selatan. Bahan uji kemudian dibersihkan dari kotoran yang melekat dengan menggunakan air mengalir, lalu dirajang, kemudian dilakukan pengeringan buah belimbing wuluh dengan di oven drying pada suhu \pm $70^{\circ} \mathrm{C}$ sedangkan daun pepaya yaitu dengan cara diangin-angin, selanjutnya diblender dan serbuk tersebut siap untuk diekstraksi dengan metode maserasi.

\section{Ekstraksi}

Serbuk buah belimbing wuluh ( Averrhoa bilimbi L ) dan daun pepaya (Carica papaya L.) masing-masing 900 g, direndam dengan etanol $70 \%$ sebanyak 1-2 cm di atas permukaan ekstrak selama 6 jam pertama sambil sesekali diaduk, kemudian diamkan selama 18 jam, maserasi di ulangi tiga kali, hasil maserat yang didapat kemudian dipisahkan dengan disaring, kumpulkan semua maserat, kemudian uapkan dengan penguap vakum atau penguap tekanan rendah hingga diperoleh ekstrak kental dengan rotavapor pada suhu $40^{\circ} \mathrm{C}$, ekstrak kental yang dihasilkan selanjutnya disimpan dan digunakan untuk perlakuan. 
Efek analgetik kombinasi ekstrak buah belimbing wuluh (Averrhoa bilimbi L) dan ekstrak daun pepaya (

Pembuatan Larutan Uji

Pembuatan larutan kontrol negatif Na-CMC 0,5\%

Larutan Na-CMC sebagai kontrol (-) diberikan secara oral. NaCMC 0,5\% dibuat larutan sebanyak 20 $\mathrm{mL}$. Menimbang serbuk Na-CMC 0,1 g dan dilarutkan aquades panas sedikit demi sedikit dan diaduk hingga homogen. Kemudian dituangkan ke labu tentukan $20 \mathrm{~mL}$ dan ditambahkan aquades hangat sampai tanda batas.

Pembuatan larutan kontrol positif sirup Asam Mefenamat

Sirup Asam Mefenamat yang digunakan adalah sirup Pondex® yang mengandung Asam Mefenamat 50 $\mathrm{mg} / 5 \mathrm{~mL}$, setelah dikonversikan digunakan sebanyak $0,13 \mathrm{~mL} / 20 \mathrm{~g} \mathrm{BB}$ mencit.

Pembuatan larutan penginduksi Asam asetat $1 \%$

Larutan asam asetat glasial $100 \%$ dipipet sebanyak $1 \mathrm{~mL}$ lalu diencerkan dengan aqua untuk injeksi hingga $100 \mathrm{~mL}$.

Penetapan dosis ekstrak dan Pembuatan larutan ekstrak

Berdasarkan

penelitian

sebelumnya, dosis ekstrak etanol belimbing wuluh sebagai analgetik 500 $\mathrm{mg} / \mathrm{kg}$ BB. Sedang untuk ekstrak daun pepaya sebagai analgetik yaitu dengan dosis 600 mg. Begitu juga untuk dosis kombinasinya dibuat dosisnya $500 \mathrm{mg} / \mathrm{kg}$ BB. Jika berat mencit rata-rata $20 \mathrm{~g} \mathrm{BB}$ maka variasi dosisnya $10 \mathrm{mg} / 20 \mathrm{~g}$ BB. Volume maksimum permberian per oral pada mencit adalah $1 \mathrm{~mL}$, dibuat stok sebanyak $20 \mathrm{~mL}$ (dalam $20 \mathrm{~mL}$ terkandung 200 mg ekstrak.

\begin{tabular}{cccc}
\multicolumn{3}{c}{ Variasi Dosis $10 \mathrm{mg} / 20 \mathrm{~g} \mathrm{BB}$} \\
\hline $\begin{array}{c}\text { Belimbing } \\
\text { No Perbandingan Wuluh } \\
\text { (mg) }\end{array}$ & $\begin{array}{l}\text { Pepaya } \\
\text { (mg) }\end{array}$ \\
\hline & & 200 & 0 \\
1 & - & 150 & 50 \\
2 & $3: 1$ & 100 & 100 \\
3 & $2: 2$ & 50 & 150 \\
4 & $1: 3$ & 0 & 200 \\
5 & - & & \\
\hline
\end{tabular}

Pengujian aktifitas analgetik

Pemberian ekstrak buah belimbing wuluh dan ekstrak daun pepaya, pertama-tama menyiapkan 21 ekor mencit putih jantan sehat yang berumur 2-3 bulan dengan berat badan 20 - $30 \mathrm{~g}$ yang sebelumnya dipuasakan terlebih dahulu, lalu membagi menjadi 7 kelompok, kelompok 1 sebagai kontrol negatif di beri suspensi $\mathrm{Na}$ - CMC 0,5\% dengan dosis $1 \mathrm{~mL}$ BB per oral, kelompok 2 sebagai kontrol positif diberi sirup asam mefenamat per oral tiap $1 \mathrm{~mL}$, setelah itu pada kelompok 3, kelompok 4, kelompok 5, kelompok 6 dan kelompok 7 masing-masing sebanyak $1 \mathrm{~mL}$ secara oral larutan stok ekstrak buah belimbing wuluh dan daun 
Efek analgetik kombinasi ekstrak buah belimbing wuluh (Averrhoa bilimbi L) dan ekstrak daun pepaya (

pepaya, setelah 30 menit seluruh kelompok hewan uji mendapat perlakuan disuntikkan intraperitonial dengan larutan asam asetat $1 \% \mathrm{v} / \mathrm{v}$ dengan pelarut aqua untuk injeksi, beberapa menit kemudian mencit akan menggeliat (kedua pasang kaki ke depan dan ke belakang, serta perut menekan lantai kandang), kemudian menghitung jumlah geliat selama 45 menit pengamatan dengan selang waktu 15 menit.

\section{HASIL PENELITIAN}

Tabel 1. Persentase daya analgetik ekstrak buah belimbing wuluh (Averrhoa bilimbi L), ekstrak daun pepaya (Carica papaya L.) dan kombinasi

\begin{tabular}{ccc}
\hline Perlakuan & $\begin{array}{c}\text { Jumlah geliat rata-rata } \\
\text { kelompok }\end{array}$ & Daya analgetik (\%) \\
\hline Ekstrak tunggal BW 0,2 g & 2,11 & 86,03 \\
Ekstrak kombinasi BW \& DP 3:1 & 6,33 & 58,1 \\
Ekstrak kombinasi BW \& DP 2:2 & 1,55 & 89,71 \\
Ekstrak kombinasi BW \& DP 1:3 & 0,33 & 97,71 \\
Ekstrak tunggal DP 0,2 g & 4,44 & 70,62 \\
Asam Mefenamat & 4,88 & 67,71 \\
\hline
\end{tabular}

Keterangan: (BW): Belimbing wuluh; (DP): Daun pepaya

\section{PEMBAHASAN}

Penelitian ini bertujuan menguji efek analgetik ekstrak buah belimbing wuluh dan ekstrak daun pepaya pada hewan coba. Obat analgetik adalah obat yang digunakan untuk menekan atau mengurangi rasa nyeri terhadap rangsangan nyeri mekanik, termik, listrik atau kimiawi di sistem syaraf pusat dan perifer. Metode yang digunakan pada penelitian kali ini yaitu metode Witkin (writhing test). Metode ini memiliki keuntungan yaitu jumlah geliat yang terjadi dapat terlihat secara nyata pada hewan coba. Hewan coba yang digunakan dalam penelitian ini adalah mencit (Mus musculus) yang berjenis kelamin jantan, dalam kondisi sehat. Tujuan pemelihan jenis kelamin jantan adalah untuk menghindari adanya interaksi obat dengan perubahan hormon yang terjadi pada mencit betina. Selain itu mencit putih jantan digunakan dengan alasan kondisi biologisnya stabil bila dibandingkan dengan mencit betina yang kondisi biologisnya dipengaruhi masa siklus estrus.

Disamping keseragaman jenis kelamin, hewan uji digunakan 
Efek analgetik kombinasi ekstrak buah belimbing wuluh (Averrhoa bilimbi L) dan ekstrak daun pepaya (Carica papaya L.) pada mencit (Mus musculus)

juga mempunyai keseragaman berat badan (antara 20-30 g), dan umur (3-4 bulan). Hal ini bertujuan untuk memperkecil variabilitas biologis antar hewan uji yang digunakan, sehingga dapat memberikan respon yang relatif lebih seragam terhadap rangsang kimia yang digunakan dalam penelitian ini.

Pada penelitian ini hewan coba dibagi menjadi tujuh kelompok dimana kelompok I diberikan Na.CMC sebagai kontrol negatif, kelompok II diberikan sirup asam mefenamat sebagai kontrol positif, kelompok III diberikan ekstrak tunggal buah belimbing wuluh $0,2 \mathrm{~g}$, kelompok IV, V, VI diberikan ekstrak kombinasi ekstrak buah belimbing wuluh dan ekstrak daun pepaya dengan perbandingan 3:1, 2:2, 1:3, kemudian pada kelompok VII diberikan ekstrak tunggal daun pepaya $0,2 \mathrm{~g}$.

Pemberian obatnya dilakukan secara oral dan diinduksi dengan asam asetat $1 \%$ secara intraperitional. Pemberian asam asetat yaitu 30 menit setelah pemberian obat karena diharapkan dalam waktu tersebut telah terjadi absorbsi obat dalam tubuh hewan coba.

Asam asetat digunakan sebagai penginduksi karena merupakan asam lemah yang tidak terkonjugasi dalam tubuh, pemberian asam asetat terhadap hewan coba akan merangsang prostaglandin untuk menimbulkan rasa nyeri karena adanya kerusakan jaringan. Kemudian diamatilah jumlah geliat yang terjadi pada hewan coba. Adanya aktifitas analgetik dalam bahan uji ditunjukkan dengan jumlah geliat yang lebih sedikit sampai lebih dari $50 \%$ dibandingkan dengan kelompok kontrol.

Ekstrak etanol buah belimbing wuluh dan daun ekstrak etanol daun pepaya serta kombinasi keduanya menunjukkan adanya jumlah geliat yang lebih sedikit sampai lebih dari $50 \%$ dibanding kelompok kontrol. Persentase daya analgetik dapat dilihat pada tabel 1 .

Presentase daya analgetik untuk mengetahui besarnya kemampuan dari ekstrak buah belimbing wuluh dan ekstrak daun pepaya serta kombinasi keduanya dalam mengurangi rasa nyeri Persentase daya analgetik yang dibandingkan dengan kontrol terlihat bahwa pada dosis kombinasi ekstrak buah belimbing wuluh dan daun pepaya 1:3 dengan rata-rata persentase 97,82 menunjukkan daya analgetik yang besar. Presentase daya analgetik kelompok perlakukan berbanding terbalik dengan jumlah kumulatif geliat, berarti jika jumlah 
Efek analgetik kombinasi ekstrak buah belimbing wuluh (Averrhoa bilimbi L) dan ekstrak daun pepaya (Carica papaya L.) pada mencit (Mus musculus)

geliat besar akan memberikan presentasi daya analgetik yang kecil, begitu pula sebaliknya.

Data yang terdistribusi normal kemudian dilanjutkan dengan uji SPSS (Statistical Product and Service Solution) for window versi 23. Data tersebut dianalisis menggunakan ANOVA untuk menentukan perbedaan antar kelompok, dari pengamatan data tersebut diperoleh nilai yang signifikan yaitu $0,000(p<0,05)$, artinya terdapat perbedaan yang nyata antara tiap kelompok. Karena hasil yang diperoleh signifikan, maka analisis dilanjutkan pada Post Hoc Tests dengan uji LSD untuk melihat perbedaan antar kelompok. Kelompok Na.CMC menunjukkan nilai yang signifikan $(p<0,05)$ terhadap Asam Mefenamat dan ekstrak buah belimbing wuluh, ekstrak daun pepaya serta kombinasi keduanya dengan dosis $0,2 \mathrm{~g}, 3: 1,2: 2$, $1: 3,0,2$ g. Hal ini berarti Na.CMC memiliki efek yang berbeda dengan efek Asam mefenamat dan ekstrak buah belimbing wuluh, ekstrak daun pepaya serta kombinasi keduanya. Sedangkan data yang tidak homogen di uji statiskit dengan cara di trans.

Perlu dilakukan penelitian lebih lanjut untuk identifikasi senyawa yang berkhasiat analgetik pada kombinasi ekstrak buah belimbing wuluh dan daun pepaya dan perlu dilakukan penelitian efek analgetik ekstrak buah belimbing wuluh dan daun pepaya dengan menggunakan dosis yang berbeda dan metode yang berbeda pula serta pelu dilakukan penelitian dengan menggunakan hewan uji yang lebih banyak dan waktu yang lebih lama.

\section{KESIMPULAN}

Hasil penelitian menyimpulkan semua kombinasi ekstrak buah belimbing wuluh dan daun pepaya memiliki aktivitas yang lebih baik sebagai analgetik dibandingkan dengan ekstrak tunggal, kombinasi yang paling optimum adalah ekstrak buah belimbing wuluh dan daun pepaya dengan perbandingan 1:3.

\section{DAFTAR PUSTAKA}

1. Alamendah. Belimbing Wuluh (Averrhoa bilimbi L) Kaya Khasiat. Alamendah.wordpress.com/2010/0 8/15/belimbing-wuluh-Averrhoabilimbi-kaya-khasiat/. 29 Desember 2018.

2. Gunawan SG. Farmakologi dan Terapi ed 5, Jakarta: Balai Penerbit FKUI, 2008.

3. Ikram EHK Eng $\mathrm{KH}$, Jalil AMM, Ismail A, Idris S, Azlan A, Nazri HSM, Diton NAM, Mokhtar RAM. Antioxidant capacity and total phenolic content of Malaysian underutilized fruits. J Food Comp Anal.2009;22:388-393. 
Efek analgetik kombinasi ekstrak buah belimbing wuluh (Averrhoa bilimbi L) dan ekstrak daun pepaya (arica papaya L.) pada mencit (Mus musculus)

4. Parekh JD, Jadeja, Chanda S. Efficacy of Aqueous and Methanol Extracts of Some Medicinal Plants for Potential Antibacterial Activity. Turkish Biology Journal.2005;29: 203-210.

5. Santhyami and Endah E. Etnobotani Tumbuhan Obat Oleh Masyarakat Adat Kampung Dukuh, Garut, Jawa Barat. Bandung: Sekolah IImu dan Teknologi Hayati. ITB, 2006.

6. Suryanto E. Fitokimia Antioksidan. Surabaya: Putra Media Nusantara, 2012.

7. Tjay TH and Rahardja K. ObatObat Penting Khasiat, Penggunaan dan Efek-Efek Sampingnya, Edisi Keenam, Jakarta: PT.Elex Media Komputindo, 2007.

8. Zakaria Z. A., Mohd N. A., Hazalin N., et al, (2007). Antinociceptive, anti-inflammatory and antipyretic effects of Muntingia calabura aqueous extract in animal models. J. Nat. Med.

9. Zakaria ZA, Mohd Nor Hazalin NA, Mohd Zaid SNH, Abdul Ghani M, Hassan MH, Gopalan HK, Sulaiman MR. Antinociceptive, antiinflammatory and antipyretic effects of Muntingia calabura aqueous extract in animal models. Journal of Natural Medicines.2007;61(4): 443448. 